\title{
Preface \\ Palaeodiversity and Palaeoecology of Iberian Ecosystems. New insights into the Phanaerozoic biotas from Spain and Portugal
}

\author{
M. Furió ${ }^{1}$, C. Martínez-Pérez², A. Santos-Cubedo ${ }^{3}$ \\ ${ }^{1}$ Institut Català de Paleontologia Miquel Crusafont, Universitat Autònoma de Barcelona. Edifici ICP, Campus de la UAB s/n, \\ 08193 Cerdanyola del Vallès, Barcelona, Spain. \\ ${ }^{2}$ School of Earth Sciences, University of Bristol, Wills Memorial Building, Queen's Road, Bristol BS8 1RJ, United Kingdom. \\ ${ }^{3}$ Grup Guix, C/Santa Lucia 75 Vila-real (12540), Castelló, Spain.
}

e-mail addresses: marc.furio@icp.cat (M.F.); Carlos.Martinez-Perez@bristol.ac.uk (C.M.P.), santos.cubedo@gmail.com (A.S.-C.))

Received: 27 November 2013 / Accepted: 3 December 2013 / Available online: 25 February 2014

Earth is currently living one of the most dramatic environmental changes in all its history. The evolution of the climatic conditions and its consequences on the planetary ecosystems are uncertain, and they could lead eventually to an irreversible ecological shift in state at a planetary scale similar to those produced by glacial dynamics, the 'Big Five' mass extinctions or the Cambrian explosion (Barnosky et al., 2012). It is evident that global dynamics influence local conditions, so now, the pertinent debate is about the extent that local factors significantly influence global ecological states. Here, ecology meets paleontology, so the variable 'time' is added to the interactions between living matter and energy. As the British poet Lord Byron stated, 'the past is the best prophet of the future'.

The fossil deposits from the Iberian Peninsula provide a high resolution data set for examining global trends. Numerous outcrops from Portugal and Spain have delivered an impressive amount of fossil organisms and their traces, not only as isolated sites but also in rather long stratigraphical series. A small, but representative sample of these localities is presented in this volume. The papers in this Special Issue stem from several works presented at the " $X$ Encuentro de Jóvenes Investigadores en Paleontologia" held in Sot de Chera (Valencia, Spain) in April 2012, with the main topic 'Palaeodiversity and Palaeoecology of Iberian Ecosystems'. More than 45 contributions were presented, providing a representative view of the state-of-art and multidisciplinary paleontological techniques carried out in Portugal and Spain. The present volume portrays a collection of synthetic works presented at the aforementioned meeting, all of them based on fossils from Iberian localities.

Understanding the past ecosystems requires a holistic approach, including systematic, palaeogeographic, palaeoecologic and evolutionary studies. Accordingly, a stratigraphic and temporal framework is necessary to confine the fossil record in space and time, as evidently shown in several papers of the volume. For instance, Martínez-Pérez and Valenzuela-Ríos (2014) describe the adaptive radiation during the Early Devonian of polygnathid conodonts from the Spanish Central Pyrenees, with the identification of several new species. Similarly, Coronado and Rodríguez (2014) describe the Carboniferous auloporid diversity, distribution and palaeocology, developing a preliminary biostratigraphic range chart for the Carboniferous auloporoids corals from the Iberian Peninsula. Using a similar approach in the Mesozoic, García et al. (2014) review the stratigraphic distribution of the Hauterivian-Albian ammonoid species in the Maestrat Basin (E Spain), providing an updated and comprehensive biostratigraphic framework as a reference for the analysis of the Lower Cretaceous strata of the Maestrat Basin.

Modern ecosystems are only a fraction of all ecosystems that have existed throughout geologic history. Therefore, the study of the structure of both past and recent communities and their response to biotic and abiotic factors is essential to understand future environmental changes. A good example focused on the Middle Triassic chondrichthyan paleocommunity from the Iberian Ranges is presented by Ferrón et al. (2014). These authors, based on isolate scales, reconstruct the 
chondrichthyan shark communities of several Iberian localities, not only concluding that they were dominated by benthic sharks, but also correlating the changes in these communities with important environmental changes - sea level fluctuations - that affected the Iberian Basin. As a result of the environmental changes, the clade Dinosauria began to dominate the Mesozoic terrestrial ecosystems, and started their reign as one of the most successful groups in the history of Earth. The fossil record of dinosaurs - both bones and tracks - is well represented in the Jurassic and Cretaceous sediments of the Iberian Peninsula. Accordingly, the interval from the Middle Jurassic to the Late Cretaceous fossil record from Portugal and Spain has delivered numerous trackways of sauropods, Dinosauria's largest representatives, evidencing gregarious and solitary movements linked to different environments (Castanera et al., 2014). However, the gregarious behavior was not limited to sauropod dinosaurs. At a lesser scale, the Lower Cretaceous tracksites from the Cameros Basin in La Rioja reveal that other dinosaur groups like theropods and ornithopods share this condition, at least for some seasons or some periods of their lives (García-Ortiz and Pérez-Lorente, 2014). Unlike Castanera et al. (2014), the data obtained from the Cameros Basin to infer patterns of gregarious behaviors in dinosaurs is not only provided by trackways, but also by dinoturbated layers.

As previously stated, the studies on palaeodiversity offer a unique opportunity to understand the diversity dynamics of the biota (Sepkoski et al., 1981), as well as their biological and environmental drivers. Several papers in this volume emphasize the important relationship between the environment and biodiversity by means of diversification or extinction processes. After the Cretaceous extinction, one of the most striking biotic turnovers in the history of life took place. In terrestrial ecosystems, the time for the supremacy of mammals arrived. A privileged order within them, the primates, experienced several evolutionary innovations, which eventually resulted in a species - among otherswith the most sophisticated brain structure, language, behavior and technology ever found in the Earth: Homo sapiens (usually known as 'mankind'). A notorious sample of the major evolutionary steps of this complicated process is also found in the Cenozoic Iberian continental record (Marigó et al., 2014). The evolution and diversity of the ursoid mammals is likewise well documented throughout the Spanish Neogene record, sometimes depicting relationship with environmental fluctuations (Abella et al., 2014). In fact, the Miocene terrestrial ecosystems are quite well represented in Spain. Good examples of this are additionally found in this volume. For instance, a sinecological analysis of the Aragonian communities reveals that the Madrid Basin showed a predominance of semiarid environments with pulses in aridity coinciding with the Global Cooling Event of the middle Miocene (García-Yelo et al., 2014). However, the diet of some mammal groups inhabiting did not reflect the environmental changes taking place in this basin, as indicated by the study on the dental microwear of the Armantomys lineage represented by $A$. aragonensis - A. tricristatus (Oliver et al., 2014). Similarly, long considered to be an abrupt replacement of faunas, the so-called 'Vallesian Crisis' appears to be a result of differential paleontological sampling after a thorough study of the small mammal assemblages from its type area, the Vallès-Penedès Basin (CasanovasVilar et al., 2014).

In younger localities, a 'hot topic' is to find out the ecological factors that might have conditioned the dispersals of early Homo into European lands. In this subject, the study of Early to Late Villafranchian large mammals from Iberian localities is a key point (Madurell et al., 2014). After finally settling in European lands, nonetheless, the last external influence that mankind had to face was perhaps the Last Glacial Maximum. After the study of some small mammal assemblages from Spain aged between 22-19 ka BP, we learned that climate harsher than today characterized this period in the Iberian Peninsula, albeit not as rigorously as elsewhere in Europe (Bañuls-Cardona et al., 2014).

The new data included in this Special Issue of the Journal of Iberian Geology provide valuable information about the interrelationships between individuals, populations, and communities throughout time, and their dynamic responses to environmental changes. We do not yet know to what degree local factors can have significant influence over global ecological states, but we are absolutely convinced that global science requires a multitude of contributions detailing lesserscale events for a better understanding of global dynamics. This volume is just one such contribution. As Editors of the present volume, we hope that this collection of papers will inspire other scientists in their research to understand and divert us from the consequences of the current and future bioclimatic changes produced by human activities.

Eventually, we would like to acknowledge all those young authors who have contributed to the success of the publication of this volume, the senior researchers (mostly supervisors of these young authors coauthoring the papers after the name of their students) and to all the people and institutions who supported the celebration of the " $X$ Encuentro de Jóvenes Investigadores en Paleontología".

\section{References}

Abella, J., Montoya, P., Morales, J. (2014): Paleodiversity of the Superfamily Ursoidea (Carnivora, Mammalia) in the Spanish Neogene, related to environmental changes. Journal of Iberian Geology, 40 (1): 11-18, doi: 10.5209/rev JIGE.2014.v40.n1.44083

Barnosky, A.D., Hadly, E.A., Bascompte, J., Berlow, E.L., Brown, J.H., Fortelius, M., Getz, W.M., Harte, J., Hastings, A., Marquet, P.A., Martínez, N.D., Mooers, A., Roopnarine, P., Vermeij, G., Williams, J.W., Gillespie, R., Kitzes, J., Marshall, C., Matzkie, N., Mindell, D.P., Revilla, E., Smith, A.B. (2012): Approaching a state shift in Earth's biosphere. Nature, 486: 52-58. doi:10.1038/nature11018. 
Bañuls-Cardona, S., López-García, J.M., Blain, H.-A., Lozano-Fernández, I., Cuenca-Bescós, G. 2014. The end of the Last Glacial Maximum in the Iberian Peninsula characterized by the small mammal assemblages. Journal of Iberian Geology, 40 (1): 19-27, doi: 10.5209/ rev_JIGE.2014.v40.n1.44085

Casanovas-Vilar, I., van den Hoek Ostende, L.W., Furió, M., P.A. Madern, P.A. (2014): The range and extent of the Vallesian Crisis (Late Miocene): new prospects based on the micromammal record from the Vallès-Penedès basin (Catalonia, Spain). Journal of Iberian Geology, 40 (1): 29-48, doi: 10.5209/rev_JIGE.2014.v40.n1.44086

Castanera, D., Vila, B., Razzolini, N.L., Santos, V.F., Pascual, C. and J.I. Canudo, J.I. (2014): Sauropod trackways of the Iberian Peninsula: palaeoetological and palaeoenvironmental implications. Journal of Iberian Geology, 40 (1): 49-59, doi: 10.5209/rev JIGE.2014.v40. n1.44087

Coronado, I., Rodríguez, S. (2014): Carboniferous auloporid distribution, palaeocology, diversity and age range from the Iberian Peninsula. Journal of Iberian Geology, 40 (1): 61-85, doi: 10.5209/rev_ JIGE.2014.v40.n1.44088

García, R., Moreno-Bedmar, J.A., Bover-Arnal, T., Company, M., Salas, R., Latil, J-L., Martín-Martín, J.D., Gomez-Rivas, E., Bulot, L.G., Delanoy, G., Martínez, R., Grauges, A. (2014): Lower Cretaceous (Hauterivian-Albian) ammonite biostratigraphy in the Maestrat Basin (E Spain). Journal of Iberian Geology, 40 (1): 99-112, doi: 10.5209/ rev JIGE.2014.v40.n1.44090

Ferrón, H., Pla, C., Martínez-Pérez, C., Escudero-Mozo, M.J., Botella, H. (2014): Morphometric Discriminant Analysis of isolated chondrichthyan scales for palaeoecological inferences: the Middle Triassic of the Iberian Chains (Spain) as a case of study. Journal of Iberian Geology, 40 (1): 87-97, doi: 10.5209/rev_JIGE.2014.v40.n1.44089

García Yelo, B.A., Gómez Cano, A.R., Cantalapiedra, J.L., Alcalde, G.M., Sanisidro, O., Oliver, A., Hernández-Ballarín, V., López-Guerrero, P., Fraile, S., Hernández Fernández, M. (2014): Palaeoenviron- mental analysis of the Aragonian (middle Miocene) mammalian communities from the Madrid Basin based on their body size diversity structure. Journal of Iberian Geology, 40 (1): 129-140, doi: 10.5209/ rev_JIGE.2014.v40.n1.44092

García-Ortiz, E., Pérez-Lorente, F. (2014): Palaeoecological inferences about dinosaur gregarious behaviour based on the study of tracksites from the La Rioja area in the Cameros Basin (Lower Cretaceous), Spain. Journal of Iberian Geology, 40 (1): 113-127, doi: 10.5209/ rev_JIGE.2014.v40.n1.44091

Madurell-Malapeira, J., Ros-Montoya, S., Espigares, M.P., Alba, D.M., Aurell-Garrido, J. (2014): Villafranchian large mammals from the Iberian Peninsula: paleobiogeography, paleoecology and dispersal events. Journal of Iberian Geology, 40 (1): 167-178, doi: 10.5209/ rev JIGE.2014.v40.n1.44093

Marigó, J., Susanna, I., Minwer-Barakat, R., Madurell-Malapeira, J., Moyà-Solà, S., Casanovas-Vilar, I., Robles, J. M., Alba, D.M. (2014): The primate fossil record in the Iberian Peninsula. Journal of Iberian Geology, 40 (1): 179-211, doi: 10.5209/rev JIGE.2014.v40.n1.44094

Martínez-Pérez, C., José Ignacio Valenzuela-Ríos, J.I. (2014): New Lower Devonian Polygnathids (Conodonta) from the Spanish Central Pyrenees, with comments on the early radiation of the group. Journal of Iberian Geology, 40 (1): 141-155, doi: 10.5209/rev_JIGE.2014. v40.n1.44095

Oliver, A., Hernández-Ballarín, V., López-Guerrero, P., García-Paredes, I., Álvarez-Sierra, M.A., Gómez Cano, A.R., García Yelo, B.A., Alcalde, G.M., Peláez-Campomanes, P. (2014): Dental microwear analysis in Gliridae (Rodentia): methodological issues and paleodiet inferences based on Armantomys from the Madrid Basin (Spain). Journal of Iberian Geology, 40 (1): 157-166, doi: 10.5209/rev_JIGE.2014. v40.n1.44096

Sepkoski, J.J, Bambach, R.K, Raup, D.M., Valentine J.W. (1981): Phanerozoic marine diversity and the fossil record. Nature, 293: 435-437. doi: $10.1038 / 293435 \mathrm{a} 0$. 